\title{
Power Play: A U.S. Senator Pushes
}

James A. Nelson, Ph.D., New Mexico State University, USA

\begin{abstract}
This case shows an American health-insurance executive being asked by a U.S. senator to "back pay" a canceled health-insurance policy so that the senator's brother's hospital bills would be paid. The reader discovers how elected officials can use their power to influence and abuse regulated industries. The reader also considers the dilemmas and consequences of pressure from elected officials to perform illegal acts. This case is appropriate for courses in Business Ethics, Insurance, and Government.
\end{abstract}

Keywords: Ethics; Politics; Insurance; Fraud; Corruption

\section{INTRODUCTION}

buse of power by elected officials is a form of corruption that is common in many parts of the world. Public officials may demand payment or other consideration for dealings that should be free of any monetary and other non-regulatory contingencies. Bribes and favors may also be initiated by individuals or organizations to obtain special treatment from politicians. In both of these scenarios, each party achieves some reward: The public official gets money and the private citizen gets services or contracts. To varying degrees around the world, corruption is embedded in the conduct of business and is accepted by both parties as the normal way of getting things done. The costs of corruption are far reaching and damaging, no matter where they occur.

Transparency International (www.transparency.org) is an independent organization dedicated to fighting global corruption by issuing a Corruption Perceptions Index and providing other anti-corruption resources. This index ranks countries according to perceived corruption as measured by surveys and assessments relating to bribery of public officials, kickbacks, embezzlement, and anti-corruption efforts. Corruption is defined as "the abuse of entrusted power for private gain". Transparency International makes the case for ethical government in its policy statement:

Citizens expect parliamentarians to maintain a high moral standard in their professional and private lives. They expect parliamentarians to serve out of conviction and a commitment to the public good, rather than for aspirations of personal power and the pursuit of private profit. In turn, they are conferred the legitimate authority to take decisions that determine the fortunes of both the state and its citizens.

Failure by parliamentarians to live up to these expectations can seriously undermine not only the trust citizens have in the ability of their elected leaders to act in the public interest but also in the legitimacy of the state and its institutions. At best, this leads to cynicism and apathy on the part of citizens. At worst, it leads to a questioning of the entire political system. It is crucial, therefore, that elected members of government act, and are seen to act, in an ethical manner.

Mechanisms are needed that tell parliamentarians in clear terms what is expected of them and what constitutes a violation of public ethics. Such mechanisms, for instance, codes of conduct, need to be enforced and well publicized so that they serve to improve the accountability of Members of Parliament (MPs) to parliament and to the general public.

The United States often prides itself as a nation of honest politicians, particularly at the national level. It consistently ranks in the top $20 \%$ of nations on the Corruption Perceptions Index. Nevertheless, the United States is by no means immune to public corruption, as indicated by the case examined in this article. 
Our case is real, involving the health-insurance industry and a long-term U.S. senator from the East. The names of the politicians involved have not been divulged because they continue to serve even though this case occurred more than 10 years ago. The source for this case is an insurance executive at another company who wishes to remain anonymous.

A large health-insurance company in a western state had a policyholder who was frequently late on premium payments. This person was not part of a group policy and was solely responsible for the premium. Payments were eventually made, and the insurance company allowed reinstatement of the policy after it was in arrears more than 90 days. There were no claims on the policy at the time of reinstatement.

After repeated late payments, the insured's brother, a long-time U.S. senator, took over payments for the policy. Bills for the policy were sent to the senator's office in Washington, DC, and were paid on time for several months. Subsequently, the senator also stopped paying the premiums for nine months, and the insurance company canceled the policy. At this point, the senator's brother was no longer covered by any health-insurance policy.

Several months later, the brother suffered serious heart problems and was hospitalized, incurring large medical expenses. This occurred without the health-insurance company's knowledge or involvement. The president of the health-insurance company then received an unexpected call from the senator, inviting him to breakfast on Saturday morning.

At breakfast, the senator asked the health-insurance company president if he would do him a favor by retroactively reinstating his brother's health insurance. The senator offered to "back pay" all missed premiums. The president responded that it was against company policy, state regulations, and the law for him to retroactively reinstate a lapsed policy and to accept back pay for lapsed policies. The president added that if the requested action were taken, the regular audits that insurance companies undergo would reveal the back-pay transaction, and there would be ethical and legal repercussions. The breakfast meeting ended, and the executive assumed the senator understood that the policy would not be reinstated, for legal and ethical reasons.

The insurance executive assumed that the problem had simply disappeared until he received a telephone call two weeks later from the state commissioner of insurance. The commissioner told the president that it would be "in your best interest" for the insurance company to retroactively reinstate the canceled policy. The president told the insurance regulator that to reinstate the policy was wrong and would surely be discovered through outside audits or by the commissioner's office's own audits. The insurance company's license to operate is controlled by the office of the commissioner that advised the president to back-date a policy. The commissioner then told the insurance company president that "you'll find a way" to cover the senator's brother. The president told the commissioner that he would comply with his wishes only if the commissioner directed him to do so in a written letter. The commissioner declined to do so, and the matter was dropped. Again the president assumed the situation was concluded by his refusal to bend to the wishes of powerful people after explaining the ethical and legal consequences of what they were asking him to do.

The health-insurance company did not reinstate the senator's brother, and the president considered the matter closed until six months later he received calls from a state senator and another U.S. senator asking him to reinstate the canceled policy. The second U.S. senator told him to "do it." Would you "do it"?

\section{TEACHING}

What is usually seen in the press about unethical behavior by elected representatives are two parties engaged in abuse, such as bribery to obtain favors. In that scenario, the elected official gains monetary or other benefits and the person giving the bribe obtains contracts, permission, or other favors. This pay-to-play scenario is common in most of the developing world. Sometimes the pay-to-play exchange is difficult to detect (e.g., loans to officials, information, favorable terms, etc., or is technically legal (campaign contributions, tickets to sporting events). In these situations, both parties benefit from the questionable behavior. In our current case, the elected official is the only party who would benefit from the unethical behavior. Our case involves a situation where power is used to influence an organization's decision through implied threats. The use of words such as "in your best 
interest," "you'll find a way," and "do it" are direct quotes from the players and are none too subtle threats of negative consequences to the insurance executive and his company. This is pure power used to bully people into illegal or unethical behavior.

What could happen to the insurance company president if he did not "fix" the problem? What could happen to the insurance company? Does the insurance company benefit in any way from this abusive relationship? How common is this type of threatening abuse compared to bribery? Which is more destructive? Why? Should the insurance executive have filed a complaint? To whom? What would the consequences have been if a complaint had been filed?

Transparency International concentrates its anti-corruption reporting and efforts on bribery of public officials. Why doesn't Transparency International report on abuse of power by public officials in their relationships and contacts with ethically responsible organizations and people? How common is this type of activity by elected officials? Do officers of the law, district attorneys, banks, insurance companies, businesses, and other organizations treat elected officials differently from how they would treat others? Why? Do U.S. senators get traffic tickets? What happens to the police officer who tries to arrest a U.S. senator? What can a police officer do when he is asked to "find a way" to make things OK? What can be done to ensure that our elected officials are people of integrity and high ethical standards?

- What rules of conduct and ethics cover U.S. senators?

- $\quad$ Are they enforceable and enforced?

\section{ACKNOWLEDGMENT}

The author would like to thank the Daniels Fund Ethics Initiative at New Mexico State University for its support in creating teaching materials based on this case.

\section{AUTHOR INFORMATION}

James A. Nelson, Ph.D. is Associate Professor of Information Systems in the College of Business at New Mexico State University. Jim is a Fellow of the Bill Daniels's Fund Ethics Initiative and does research and develops teaching materials on Ethics in Business and in Information Systems. He is a graduate of New Mexico State University, Drake University, and the University of Missouri-Columbia. E-mail: jnelson@ad.nmsu.edu 


\section{NOTES}

